Available online on 15.7.2018 at http://ujpr.org
Universal Journal of Pharmaceutical Research
An International Peer Reviewed Journal
Open access to Pharmaceutical research

\title{
PREVALENCE OF HELICOBACTER PYLORI AMONG ASYMPTOMATIC POPULATIONS IN SANA'A, YEMEN

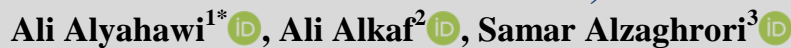 \\ ${ }^{1}$ Department of Pharmacy, Faculty of Medical Sciences, Al-Razi University, Republic of Yemen. \\ ${ }^{2}$ Faculty of Pharmacy, Sana'a University, Republic of Yemen. \\ ${ }^{3}$ Health office, Sana'a, Republic of Yemen.
}

\section{ABSTRACT}

Objective: Helicobacter pylori consider the most important cause of chronic gastritis and also the most important etiological factor responsible for the duodenal and gastric ulcer and have an important role in the pathogenesis of gastric cancer.

The aim of the present study to know the prevalence of $H$. pylori among the khat chewing adults in compared to non-khat chewing among asymptomatic populations.

Methods: A total of 82 healthy subjects were screened to find out the prevalence of Helicobacter pylori using stool antigen card test during the period started in 16 April 2018 and ending in 8 May 2018 in Sana'a, Yemen. Predesigned questionnaire was used to collect information such as age, sex, education status, khat chewing, smoking, tobacco chewing, occupation, and tests results all above data were recorded for each subject.

Results: Patients who had taken proton pump inhibitors or antibiotic for a month prior to study were excluded. Out of these 82 asymptomatic individuals, 36 were found positive for Helicobacter pylori by the test, giving a prevalence of $43.9 \%$. A prevalence of $26.9 \%$ (62.9\% of khat chewing) was khat chewing individuals and it had statistically significant difference. A prevalence of $14.6 \%$ was seen among cigarette smoking participants.

Conclusion: The present study revealed substantial prevalence of Helicobacter pylori in khat chewing healthy subjects. A higher prevalence of Helicobacter pylori seen in these subjects may be contributed to khat chewing. Identification of khat chewing populations, who do not show symptoms of Helicobacter pylori infection, is essential for controlling the infection and it still remains a challenge for the clinicians.

Keywords: Asymptomatic, H. pylori, khat chewing, prevalence, risk factors, stool antigen test.

Article Info: Received 1 April 2018; Revised 20 May; Accepted 29 June, Available online 15 July 2018

口不的回 Cite this article-

Ali Alyahawi, Ali Alkaf, Samar Alzaghrori. Prevalence of Helicobacter pylori among asymptomatic populations in Sana'a, Yemen. Universal Journal of Pharmaceutical Research 2018; 3(3): 30-34.

DOI: https://doi.org/10.22270/ujpr.v3i3.163

Address for Correspondence

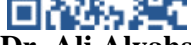

Dr. Ali Alyahawi, Department of Pharmacy, College of Medical and Health Sciences, Al-Razi University, Republic of Yemen. Email: alyahawipharm@yahoo.com

\section{INTRODUCTION}

Helicobacter pylori, previously known as Campylobacter pylori, is a gram-negative, microaerophilic bacterium usually found in the stomach. It was identified in 1982 by Australian scientists Barry Marshall and Robin Warren. Over $80 \%$ of individuals infected with the bacterium are asymptomatic, and it may play an important role in the natural stomach ecology ${ }^{1}$. More than $50 \%$ of the world's populations have $H$. pylori in their upper gastrointestinal tract ${ }^{2}$. Infection is more common in developing countries than Western countries ${ }^{3}$. Helicobacter pylori consider the most important cause of chronic gastritis and also the most important etiological factor responsible for the duodenal and gastric ulcer and have an important role in the pathogenesis of gastric cancer ${ }^{4}$. In a case control study in Nairobi country the prevalence of $H$. pylori infection was found to be higher among khat chewers, indicating that Khat chewing could be a predisposing factor to gastrointestinal disorders ${ }^{5}$. Also In another study the prevalence of gastrointestinal disorders was found to be higher among khat chewers, indicating that khat chewing could be a predisposing factor to gastrointestinal disorders and $H$. pylori infection. Community-based awareness creation about the adverse effect of khat use is thus recommended ${ }^{6}$. Raja'a YA et al., revealed in his study that khat chewing is significantly associated with duodenal ulcer due to stress that follows khat chewing. This phenomenon is very common and is induced by the effect of amphetamine like action of cathine present in khat. Another possible factor can be due to Helicobacter pylori associated with khat chewing ${ }^{7}$. 
Khat is an evergreen plant found commonly grown in Yemen, Ethiopia, Kenya, Sudan, Madagascar and South Africa ${ }^{8}$. The plant is known by different names in different countries but in most of the literature it is known as Khat'. People chew the leaves and young bud of khat for social and psychological reasons ${ }^{10,11}$. The psycho-stimulant effect of khat is due to the alkaloid chemical ingredient cathinone present in the fresh leaves of the khat plant ${ }^{12,13}$. Many people use khat for different purposes: for social recreation, to keep awake while driving long distances ${ }^{14,15}$, to reduce physical fatigue and to work hard for a long time ${ }^{16}$. It is believed that students in colleges and universities commonly use khat to improve their academic performance but the fact is the opposite. The result of one study showed that the mean cumulative Graded Point Average (GPA) of non-chewers was found to be significantly higher than that of chewers ${ }^{17,18}$. The astringent characteristics of the tannins in khat accounts for periodontal disease, stomatitis, oesophagitis and gastritis ${ }^{12}$. Tannins and cathinone contribute to constipation, the most common medical complaint of the khat user. In a randomized controlled trial, Heymann et al., reported a delay in gastric emptying after chewing khat, which was attributed to the sympathomimetic action of the cathinone ${ }^{19}$. Moreover, Gunaid et al., ${ }^{20}$. found out that khat prolongs entire gut motility and Makonnen et al., reported that khat produced constipation in mice and an antispasmodic action on guinea-pig isolated ileum ${ }^{21}$. The antispasmodic effect of khat extract was observed to be similar to that of d-amphetamine.

Khat is abundantly available in Yemen and is a highly valued export commodity in the country. The number of khat chewers has significantly increased in this country and khat consumption has become popular in all segments of the Yemeni population ${ }^{16,22}$. There were many previous studies reported a positive association between Khat chewing and gastrointestinal disorders such as dental problems, gastritis and constipation $^{12,19,20,21}$. According to some researchers, hemorrhoids are also considered to have associations with khat chewing ${ }^{21,23}$. In developing countries such as Yemen, there was no study conducted to assess the prevalence and the association between the khat chewing in compared to non-khat chewing in asymptomatic populations. Therefore, it is important to study prevalence of $H$. pylori infection and the associated risk factors among these subjects.

\section{MATERIALS AND METHODS}

A total of 82 healthy subjects were screened to find out the prevalence of Helicobacter pylori using Stool Antigen card test during the period started in 16 April 2018 and ending in 8 May 2018 at Sana'a, Yemen. Predesigned questionnaire was used to collect information such as age, sex, education status, khat chewing, smoking, tobacco chewing, occupation, and tests results all above data were recorded for each subject. Individuals who had taken proton pump inhibitors or antibiotic for a month prior to study were excluded. Data were analyzed by the chi-square test to compare the association between different variables and positive Helicobacter pylori rates. A value of $P$ $<0.05$ was considered statistically significant. Calculations were done using the software package SPSS 21.0.

Table 1: Distribution of $\boldsymbol{H}$. pylori according to gender and education status.

\begin{tabular}{|c|c|c|c|c|c|c|c|}
\hline \multicolumn{2}{|c|}{ Variable } & \multicolumn{2}{|c|}{ Stool Antigen Result } & \multirow[t]{2}{*}{ Total } & \multirow{2}{*}{$\begin{array}{c}P \text { - } \\
\text { value }\end{array}$} & \multicolumn{2}{|c|}{ 95\% Confidence Interval } \\
\hline & & ve- & ve+ & & & Lower & Upper \\
\hline \multirow[t]{3}{*}{ Gender } & $\mathrm{M}$ & 28 & 22 & 50 & 0.982 & 0.405 & 2.421 \\
\hline & $\mathrm{F}$ & 18 & 14 & 32 & & & \\
\hline & Total & 46 & 36 & 82 & & & \\
\hline \multirow{3}{*}{$\begin{array}{l}\text { Education } \\
\text { status }\end{array}$} & No & 4 & 4 & 8 & 0.71 & 0.177 & 3.281 \\
\hline & Yes & 42 & 32 & 74 & & & \\
\hline & Total & 46 & 36 & 82 & & & \\
\hline
\end{tabular}

\section{RESULTS}

A total of 82 study participants were included in the present study. Fifty patients of the study sample were male and 28 of them had positive stool antigen result. In addition, 18 of thirty two females had positive stool antigen result and 14 had negative result. The relationship between stool antigen result and sex was not statistically significant $(P$-value $=0.9821)$. In other hand, only 8 patients had not level of education. However, the relationship between stool antigen result and education status was not observed $(P$-value $=0.71)$. In the current study, there was a statistically significant difference between stool antigen result and Khat chewing subjects $(P$-value $=0.003) .47$ of the study sample were not khat chewing and 33 of them had negative stool antigen result. However, 22 of 35 study participants, that were khat chewing subjects, had positive stool antigen result (Table 2). The same result was observed between stool antigen result and cigarettes smoking subjects $(P$-value $=0.002)$. In this study, 12 patients of 15 smoked patients had positive stool antigen result. In contrast, no relationship was observed between stool antigen result and tobacco chewing $(P$-value $=0.119)$. There were 36 of 79 nontobacco chewing subjects had positive stool antigen result (Table 2). Relationship between stool antigen result and age groups was not statistically significant. However, 43 of study sample were subjects aged 20-29 years; 16 of them had positive stool antigen result (Table 3). Result in this Table 3 shows that significantly relationship $(P$-value $=0.03)$. Physicians 13 out of 15 had negative stool antigen result. On other hand, 12 housewives of 18 had positive stool antigen result. However, 5 of 12 students had positive stool antigen result and 7 of them had negative. Sixty seven of the study sample were not cigarette smoking and 20 of them had positive stool antigen result. 
Table 2: Distribution of $\boldsymbol{H}$. pylori according to khat chewing, cigarettes smoking, and tobacco chewing.

\begin{tabular}{|c|c|c|c|c|c|c|c|}
\hline \multirow{2}{*}{\multicolumn{2}{|c|}{ Variable }} & \multicolumn{2}{|c|}{$\begin{array}{c}\text { Stool Antigen } \\
\text { Result }\end{array}$} & \multirow[t]{2}{*}{ Total } & \multirow[t]{2}{*}{$P$-value } & \multicolumn{2}{|c|}{$\begin{array}{c}95 \% \text { Confidence } \\
\text { Interval }\end{array}$} \\
\hline & & -ve & + ve & & & Lower & Upper \\
\hline \multirow{3}{*}{$\begin{array}{l}\text { Khat } \\
\text { Chewing }\end{array}$} & No & 33 & 14 & 47 & 0.003 & 1.577 & 10.088 \\
\hline & Yes & 13 & 22 & 35 & & & \\
\hline & Total & 46 & 36 & 82 & & & \\
\hline \multirow{3}{*}{$\begin{array}{l}\text { Cigarettes } \\
\text { Smoking }\end{array}$} & No & 43 & 24 & 67 & 0.002 & 1.839 & 27.927 \\
\hline & Yes & 3 & 12 & 15 & & & \\
\hline & Total & 46 & 36 & 82 & & & \\
\hline Tobacco & No & 43 & 36 & 79 & 0.119 & 0.445 & 0.666 \\
\hline Chewing & Yes & 3 & 0 & 3 & & & \\
\hline
\end{tabular}

Table 3: Distribution of $\boldsymbol{H}$. pylori according to age group and occupation.

\begin{tabular}{|c|c|c|c|c|c|}
\hline \multirow{2}{*}{\multicolumn{2}{|c|}{ Variable }} & \multicolumn{2}{|c|}{ Stool Antigen Results } & \multirow[t]{2}{*}{ Total } & \multirow[t]{2}{*}{$P$-value } \\
\hline & & -ve & $+\mathrm{ve}$ & & \\
\hline \multirow{5}{*}{ Patient Age } & $20-29$ & 27 & 16 & 43 & \multirow{5}{*}{0.163} \\
\hline & $30-39$ & 16 & 13 & 29 & \\
\hline & $40--49$ & 3 & 4 & 7 & \\
\hline & $>=50$ & 0 & 3 & 3 & \\
\hline & Total & 46 & 36 & 82 & \\
\hline \multirow{14}{*}{ Occupation } & Accountant & 1 & 2 & 3 & \multirow[t]{14}{*}{0.030} \\
\hline & Businessman & 3 & 3 & 6 & \\
\hline & Physician & 13 & 2 & 15 & \\
\hline & Driver & 1 & 0 & 1 & \\
\hline & Engineer & 3 & 1 & 4 & \\
\hline & Housewife & 6 & 12 & 18 & \\
\hline & Nurse & 6 & 1 & 7 & \\
\hline & Pharmacist & 3 & 1 & 4 & \\
\hline & Policeman & 2 & 1 & 3 & \\
\hline & Security & 0 & 3 & 3 & \\
\hline & Student & 7 & 5 & 12 & \\
\hline & Teacher & 1 & 3 & 4 & \\
\hline & $\begin{array}{l}\text { Radiology } \\
\text { technician }\end{array}$ & 0 & 2 & 2 & \\
\hline & Total & 46 & 36 & 82 & \\
\hline
\end{tabular}

\section{DISCUSSION}

The number of khat chewers has significantly increased in Yemen and khat consumption has become popular in all segments of the Yemeni populations. According to previous studies, Khat chewing had a positive association with gastrointestinal disorders such as dental problems, gastritis and constipation ${ }^{6}$. Yet, in Yemen, there have been no study reports showing the association between khat chewing and positively $H$. pylori in asymptomatic populations. In the present study, there was a significant association between khat chewing and positively $H$. pylori test $(P$-value $=0.003)$. The overall prevalence of $H$. pylori infection among participants was $43.9 \%$, which is comparable with other findings reported in Ethiopia ${ }^{24}$. In a study conducted on healthy Omani blood donors, the overall prevalence for Helicobacter pylori was $69.5 \%{ }^{25}$. In a study from India, 254 individuals were screened for Helicobacter pylori which were positive in $56.7 \%$ asymptomatic individuals ${ }^{26}$. The overall prevalence recorded in current study $(43.9 \%)$ is less in comparison to the other studies. This can be explained by the fact that prevalence of $H$. pylori varies widely by geographic area, age, race, and ethnicity and socioeconomic status. Similar results were shown in a study from Kanpur, India, where $44.23 \%$ asymptomatic subjects positively Helicobacter pylori test ${ }^{27}$. In the current study, $62.9 \%$ of khat chewers had positively $H$. pylori by stool antigen card test. This prevalence was higher than other study (Moharram et al.,) which showed that the prevalence of $H$. pylori infection among Kath chewing subjects was $21.4 \%{ }^{28}$. This agree with (Raja'a et al.,) who showed that this effect can be due to $H$. pylori associated with khat chewing, beverages consumed during the session or insecticides and chemicals used for growing the khat plants ${ }^{7}$. Life style habits have been recognized as important risk factors for acquisitions of various infections, including $H$. pylori infection. Lots of researchers reported inconsistent results regarding the association of cigarettes smoking and its prevalence to $H$. pylori infection $^{24}$. According to study findings, smoking showed a trend of significant association with $H$. pylori infection. There was correlation between smoking and H. pylori positivity. Similar results have been reported in many previous studies ${ }^{29}$. Another major health concern is the concurrent use of tobacco and khat in countries where these substances are used in combination, as tobacco use is a well-known factor for the development of various diseases. It has been reported that up to $61 \%$ of khat chewers smoke cigarettes $^{30}$ and that smokers usually consume more cigarettes during khat chewing sessions ${ }^{31}$. In a recent study, approximately $42.9 \%$ of khat users reported use of tobacco, implying that khat chewing might serve as a "gateway" to tobacco use. A recent systemic review also showed that the prevalence of tobacco use among 
khat chewers is significant, especially among high school and university students, and health-care workers in certain African countries and the Middle East. It is clear that concomitant khat chewing and tobacco use has several adverse effects. First, a combination of these two deleterious habits could potentiate the detrimental effects of each other in the causation of various systemic and oral health problems, including malignant and premalignant oral lesions. Second, as the co-occurrence of khat chewing and tobacco smoking dependence is increasing remarkably, khat use might interact with tobacco use, thus hampering tobaccocessation programs ${ }^{32}$. Advanced molecular based studies have revealed that pathogenicity of $H$. pylori is predominantly influenced by smoking. Smoking might be a major risk factor entailed in modulating the susceptibility of an individual suffering with ulcers to $H$. pylori infection. Evidently, study on $H$. pylori positive asymptomatic and symptomatic subjects with acid peptic disease showed that the risk of virulent infection was escalated by smoking in both groups of individual $^{33}$

Table 4: Distribution of cigarettes smoking subjects according to khat chewing.

\begin{tabular}{ccccc}
\hline Variable & \multicolumn{2}{c}{ Khat chewing } & Total & \% \\
\cline { 2 - 3 } & No & Yes & & \\
\hline Cigarettes & 47 & 20 & 67 & 81.7 \\
Smoking & 0 & 15 & 15 & 18.3 \\
Total & 47 & 35 & 82 & 100 \\
\hline
\end{tabular}

Statistically significant association was observed $(P$ value $=0.030$ ) in the prevalence of $H$. pylori infection and type of occupations in this study which is in line with other studies ${ }^{34,35}$. Presumably, the variation in prevalence could be due to the difference in the lifestyles, exposure to potential environmental sources and habits. In current study, age wise distribution showed maximum prevalence in the age group of 2029 years; 30-39 years was $(44.4 \%) ; 36.1 \%$ respectively, and minimum in the age group of more than 50 years $(8.3 \%)$. This goes in accordance with a similar Indian study in which the maximum prevalence was in the age group of 30-39 years (50.7\%) and minimum in the age group of more than 70 years $(20 \%)^{27}$. In a study from Mumbai, age related prevalence of Helicobacter pylori showed similar results as in current study with maximum prevalence of $58 \%$ in the age group of $30-39$ years $^{36}$. Current study revealed that there was not a correlation between sex and $H$. pylori positivity $(P=0.982$, this result is in agreement with study performed by (Abo-Shadi et al., $)^{37}$, but disagree with other studies (A-Ameri and Alkadasi) ${ }^{29}$. Among the socio-demographic characteristics of the participants, statistically significant difference was not obtained for educational attainment which is in agreement to studies ${ }^{38,39}$ and inconsistent to other studies ${ }^{34,40}$. The absences of association in this study might be due to less number of non-educated subjects that cause difficulty to compute the association.

\section{CONCLUSION}

Based on the findings, it was concluded that khat chewing is a common practice among Yemeni adults. The result of this study depicts that $H$. pylori prevalence are significantly associated with khat chewing. Identification of khat chewing populations, who do not show symptoms of Helicobacter pylori infection, is essential for controlling the infection and it still remains a challenge for the clinicians

The present study findings call for further research especially in a longitudinal study which is more costly and time-consuming to strengthen current current study findings. Regulatory bodies may need to devise strategies to counter the expansion of Khat chewing and other substance uses which pose continuing public health risks. Community based health education is also needed.

\section{AUTHOR'S CONTRIBUTION}

The manuscript was carried out, written, and approved in collaboration with all authors.

\section{ACKNOWLEDGEMENTS}

The authors extend their thanks and appreciation to the Al-Razi University, Republic of Yemen to provide necessary facilities for this work.

\section{CONFLICT OF INTEREST}

The authors declare that they have no competing interests.

\section{REFERENCES}

1. Blaser MJ. "Who are we? Indigenous microbes and the ecology of human diseases". EMBO Reports 2006; 7 (10): 956-60. https://doi.org/10.1038/sj.embor.7400812

2. Amieva M, Peek RM Jr. Pathobiology of Helicobacter pylori-induced gastric cancer. Gastroent 2016; 150 (1): 64-78. https://doi.org/10.1053/j.gastro.2015.09.004

3. Bakri MM. Prevalence of Helicobacter pylori infection and the incidence of ureA and clarithromycinresistance gene 23S rRNA genotypes status in Saudi Arabia. Saudi J Biol Sci 2013; 20(1):75-8 https://doi.org/10.1016/j.sjbs.2012.10.006

4. Kim W, Moss SF. The role of $H$. pylori in the development of stomach cancer. Oncol Rev 2008; 1(1): 165-168.

5. Hassan M A, Mohamed K, Zipporah N, Hudson L. Khat (Catha edulis) Use is Associated with the Development of Gastritis among Adults in Nairobi County, Kenya, East African Med J 2014; 91(6):12-19.

6. Nigussie T, Gobena T, Mossie A. Association between Khat Chewing and Gastrointestinal Disorders: A Cross Sectional Study, Ethiop J Health Sci. 2013; 23(2): 123130. PMID: 23950628

7. Raja'a YA, Noman TA, Al-Warafi AK, Al Mashraki NA, $\mathrm{Al}$ Yosofi AM. Khat chewing is a risk factor of duodenal ulcer. Saudi Med J 2000; 21(9):887-8.PMID: 11376372

8. Cox G, Rampes H. Adverse effects of khat: A review. Advances in Psychiatric Treatment. 2003:456-463. https://doi.org/10.1192/apt.9.6.456

9. Nencini P, Grassi MC, Botan AA, Asseyr AF, Paoli E. Khat chewing spread to the Somali community in Rome. Drug Alcohol Depend 1988; 23:255-158. https://doi.org/10.1016/0376-8716(89)90089-6

10. Al Motarreb A, Baker K, Broadley KJ. Khat: Pharmacological and Medical Aspects and its social use in Yemen. Phytother Res 2002; 16:403-413. https://doi.org/10.1002/ptr.1106 
11. Nordal A. Khat: Pharmacognostical Aspects. Bull Narc. 1980; 32:51-64. PMID: 23950628

12. WHO Report. Review of the Pharmacology of Khat. Bull Narc. 1980; 32:83-93. https://doi.org/10.1016/03063623(84)90156-3

13. Elmi AS. Khat Consumption and problems in Somalia; Proceedings of the International Conference on Khat; Antanarivo, Madagascar. 1983. 17-21.

14. Kalix P. The Pharmacology of Khat; International Symposium; Addis Ababa. 1984. 69-73. PMID: 23950628

15. Amaha M. Clinical Aspects of Khat (Catha edulis Forsk) Proceedings of the International Symposium on Khat. 1983:77-83. PMID: 23950628

16. Atalay A, Dereje K, Kullgren G. The prevalence and socio-demographic correlates of khat chewing in Butajira, Ethiopia. Acta Psychiatry 1999; 397:84-91. https://doi.org/10.4314/ejhs.v21i1.69042

17. Andualem M, Zeleke M. Khat (Catha edulis Forsk) chewing, socio-demographic description and its effect on academic performance, Jimma University students. Ethiop Med J 2004; 42(2):125-136.

https://doi.org/10.4103/2141-9248.177992

18. Kalayu M, Andualem M, Yeshigeta G. Effect of substance use on academic achievement of health officer and medical students of Jimma University, Southwest Ethiopia. Ethiop J Health Sci 2009; 19(3):155-163.

19. Heymann TD, Bhupulan A, Zureikat NE, Drinkwater C, Giles P, Murray-Lyon IM. Khat chewing delays gastric emptying of a semi-solid meal. Alimentary Pharmacology and Therapeutics 1995; 9:81-83. https://doi.org/10.1111/j.1365-2036.1995.tb00356.x

20. Gunaid AA, El-Khally FM, Hassan NA, Murray-Lyon IM. Chewing qat leaves slows the whole gut transit time. Saudi Medical J 1999; 20:444-447.

21. Eyassu M. Constipating and spasmolytic effects of khat (Catha edulis Forsk) in experimental animals. Phytomedicine 2000; 74:309-312. https://doi.org/10.1016/S0944-7113(00)80049-5

22. Selassie SG, Gebre A. Rapid assessment of drug abuse in Ethiopia. Bull Narc. 1996; 48:53-63. PMID: 9839035

23. Daisy A, Carlos A, Hildegardo C. Evaluation of constipation. Am Fam Physician 2002; 65:2283-2290. https://doi.org/10.1055/s-0032-1301753

24. Alebie G, Kaba D. Prevalence of Helicobacter pylori Infection and Associated Factors among Gastritis Students in Jigjiga University, Jigjiga, Somali Regional State of Ethiopia. J Bacteriol Mycol 2016; 3(3): 00060 https://doi.org/10.15406/jbmoa.2016.3.00060

25. Al-Balushi MS, Al-Busaidi JZ, Al-Daihani MS, Shafeeq MO, Hasson SS. Sero prevalence of Helicobacter pylori infection among asymptomatic healthy Omani blood donors. Asian Pac J Trop Dis 2013; 3(2): 146-149. https://doi.org/10.1016/S2222-1808(13)60059-6

26. Singh V, Trikha B, Nain CK. Epidemiology of Helicobacter pylori and peptic ulcer in India. $\mathrm{J}$ Gastroenterol Hospital 2002; 17 (6): 659-665. PMID: 23168695

27. Rastogi M, Rastogi D, Singh S, Agarwal A, Priyadarshi BP, Middha T. Prevalence of Helicobacter pylori in asymptomatic adult patients in a tertiary care hospital: A cross sectional study. Biomed Res 2014; 25 (4): 117-122

28. Moharram ASS, Abdulhafiz Alqady A., Alhetary A.A. Prevalence of Helicobacter pylori among Gastritis Patients in Sana'a, Yemen Int J Curr Microbiol App Sci 2015; 4(3): 769-778. https://doi.org/10.22270/ujpr.v3i3.163

29. A-Ameri GA, Alkadasi MN. The prevalence of Helicobacter pylori and risk factors infection associated in Taiz city, Yemen. Int J Current Microbiol App Sci 2013; 2 (8): 226-233. https://doi.org/10.1155/2014/481365

30. Nakajima M, al'Absi M, Dokam A, Alsoofi M, Khalil NS, Al Habori M. Gender differences in patterns and correlates of khat and tobacco use. Nicotine Tob Res 2013; 15:11301135. https://doi.org/10.1093/ntr/nts257

31. Kassim S, Islam S, Croucher RE. Correlates of nicotine dependence in U.K. resident Yemeni khat chewers: A cross-sectional study. Nicotine Tob Res 2011; 13:12401249. https://doi.org/10.1093/ntr/ntr180

32. Kassim S, Jawad M, Croucher R, Akl EA. The epidemiology of tobacco use among Khat users: A systematic review. Biomed Res Int 2015:313692. https://doi.org/10.1155/2015/313692

33. Ghosh P, Bodhankar SL. Association of Smoking, alcohol and NSAID use with expression of cag A and cag T genes of $H$. pylori in salivary samples of asymptomatic subjects. Asian Pac J Trop Biomed 2012; 1(1): 479-484. https://doi.org/10.1016/S2221-1691(12)60080-X

34. Abebaw W, Kibret M, Abera B. Prevalence and Risk factors of $H$. pylori from Dyspeptic patients in Northwest Ethiopia: A Hospital Based Cross-sectional Study. Asian Pac J Cancer Prev 2014; 15 (11):4459-4463 https://doi.org/10.1371/journal.pone.0187113

35. Nurgalieva ZZ, Malaty HM, Graham DY, Almuchambetova R, Machmudova A, Kapsultanova D, et al. Helicobacter pylori infection in Kazakhstan: Effect of water source and household hygiene. Am J Trop Med Hyg 2002; 67(2):201-206 https://doi.org/10.4269/ajtmh.2002.67.201

36. Gill HH, Desai HG, Majumdar P, Mehta PR, Prabhu SR. Epidemiology of Helicobacter pylori: the Indian Scenario. Ind j Gastroenterol. 1993; 12(1): 9-11. PMID: 8330925

37. Abo-Shadi MA, El-Shazly TA, Al- Johani MS. Clinical, Endoscopic, Pathological and Serological Finding of Helicobacter pylori infection in Saudi patients with upper gastrointestinal diseases. British J Med Medical Res 2013; 3 (4): 1109-1124.https://doi.org/10.1016/j.ajg.2010.01.005

38. Shi R, Xu S, Zhang H, Ding Y, Sun G, Huang X. Prevalence and Risk Factors for Helicobacter pylori infection in Chinese populations. Helicobacter 2008; 13(2):157-165 https://doi.org/10.1111/j.1523-5378.2008.00586.x

39. Aguemon DB, Struelens JM, Massougbodji A, Ouendo ME. Prevalence and risk-factors for Helicobacter pylori infection in urban and rural Beninese populations. Clin Microbiol Infect 2005; 11(8): 611-617. https://doi.org/10.1111/j.1469-0691.2005.01189.x

40. Dilnessa M, Amentie M. Prevalence of Helicobacter pylori and risk factors among dyspepsia and non-dyspepsia adults at Assosa General Hospital, West Ethiopia: A comparative study. Ethiop J Health Dev 2017; 31(1):4-12. 